\title{
THE EFFECT OF CURRICULAR AND EXTRACURRICULAR ACTIVITIES ON UNIVERSITY STUDENTS' ENTREPRENEURIAL INTENTION AND COMPETENCES
}

This paper examines the effect of curricular and extracurricular activities on the entrepreneurial motivation and competences of university students. In order to address these issues, we have used Azjen's (1991, 2002) model of planned behaviour, including curricular and extracurricular activities, analysing their effect on university students' attitude and behavioural control and their entrepreneurial intention as well as competences. Using a convenience sample of university students, we chose two Spanish institutions, with a total sample size of 1,475 students. Our analysis demonstrates the effects of curricular and extracurricular activities on the entrepreneurial intention of university students. Such activities generate positive attitudes for entrepreneurship but at the same time they lower capacity and intention to start a business. Similarly, the study shows the different effects of such variables on the competencies for entrepreneurship. Strategic and methodological implications of these results are discussed.

\section{INTRODUCTION}

The importance of universities in the task of orienting graduates to develop their entrepreneurial intention has been stressed by numerous researchers. Over the years researchers have tried to provide an answer to these questions: What, How and When to teach at universities in order to foment entrepreneurial initiative? (Krueger et al., 2000; Autio et al., 2001; Kirby, 2005; Liñan and Chen, 2009; Nabi et al., 2006; Nabi and Holden, 2008; Fayolle et al., 2006; Cranmer, 2006: Pittaway and Cope, 2007; Buckland, 2009; De Silva, 2015). Taking into account the importance of entrepreneurship in the economy (Acs and Szerb, 2007), universities devote considerable effort to developing both curricular and extracurricular activities to encourage entrepreneurial intention in their students (Fayolle et al., 2006; Shinnar et al., 2009; Souitaris et al., 2007; Wilson et al., 2007; Davey et al., 2010; Ertuna and Gurel, 2011; Thomas et al., 2014).

In recent years, academicians have developed a growing interest in the effectiveness of those efforts on entrepreneurship initiative (Kirby, 2005; Fayolle et al., 2006; Shinnar et al., 2009; Souitaris et al., 2009; Markman et al., 2002; Boissin et al., 2009a, b). The results of such research have produced numerous studies on education in entrepreneurship (Alexei and Kolvereid, 1999; Karanja et al., 2012; Shinnar et al., 2009; Soutaris et al., 2007; Liñan and Chen, 2009; Venciana et al., 2005; Peterman and Kennedy, 2003), but these tend to be limited and 
contradictory (Collins et al., 2004; Guerrero et al., 2008; Gurel et al., 2010; Thompson et al., 2010; $\mathrm{Wu}$ and $\mathrm{Wu}, 2008)$. While some researchers complain that formal education reduces the individual's desire for entrepreneurship (e.g., Shapero and Sokol, 1982; Collins et al., 2004), others consider that education increases the individual's entrepreneurship motivation (e.g., Davidsson, 1995; Boissin et al., 2009a). This controversy was the starting point of some studies whose aim was to explain the effectiveness of university education in entrepreneurial motivation. Following the Global Entrepreneurship Monitor, Acs et al., (2005) point out that some of the actions developed by universities were not channelled correctly. In this way, Laukkanen (2000) and Kirby (2005) indicate that nowadays, universities worldwide, instead of instilling an entrepreneurial spirit, merely teach entrepreneurship and business. Smith et al. (2006), Hartshorn and Hannon (2005), and Decramer et al. (2012) mention that in spite of many existing initiatives regarding the application of educational models designed to develop entrepreneurship intention, no model has been consolidated yet, and the lack of this general model means that university attempts to develop entrepreneurial initiative lack effectiveness. In spite of these efforts, the controversy continues, with this research question being a major debate issue: the role that university should play in developing and fomenting university students' entrepreneurship motivation.

Our work tries to shed light on this question. Based on the issues raised above, our study focuses on the effect of curricular and extracurricular activities on entrepreneurial motivation. In order to analyse this effect, we have focused on undergraduate university programmes. According to Kirby (2005), and Fayolle et al. (2006), the objectives of higher education as related to entrepreneurship should be aimed at (1) developing an entrepreneurship intention in students through an increase in awareness and motivation; (2) developing the entrepreneurial competences needed to identify and exploit business opportunities; and (3) providing the necessary knowledge to start a business and manage its growth. We have extended our study to degrees other than Business and Marketing, using a convenience sample of university students which is typical in this kind of researches (Coduras et al., 2008; Dohse and Walter, 2010).

We have chosen the Spanish context for our study. In this regard, the situation of youth employment (under 25 years) with over 50\% unemployment is considered by the Spanish government as critical and their policies are oriented to support entrepreneurs and to promote their internationalization (BOE, 2013). Along with this, during the recent economic crisis the 
number of entrepreneurs between 15 and 39 years decreased by 30\% (Eurostat, 2015), thus the study of the university effectiveness in the training of entrepreneurs becomes a key element. Responding to this interest, Spanish universities are developing entrepreneurship programs, both formal training in entrepreneurship as well as short courses complemented with extracurricular activities (University- Foundation Company 2012). However, as the GEM (2015) reports points out, there has been no advancement of the young university segment with regards to its vocation to develop a business.

We chose two Spanish institutions, with a total sample of 1,475 university students. The first Higher Education institution is ESIC Business and Marketing School. This institution focuses on Business and Marketing, and is characterized by offering extensive experience in entrepreneurial training, with a wide range of related curricular \& extracurricular activities. In fact, $25 \%$ of formal training credits correspond to subjects related with the entrepreneurship. Moreover, ESIC has an entrepreneurship center whose activities are entrepreneurship advice, technical support and promotion of projects through an incubator and entrepreneurship awards.The second institution is ESNE (University School of Design, Technology and Innovation) which, while it does not have specific entrepreneurship training, it does offer new university degrees oriented to stimulate the development of entrepreneurial initiative among its students. The first question addressed in this paper is the effect that curricular and extracurricular activities have on the acquisition of entrepreneurial competences in the two institutions. The second question analysed is how these activities influence the dynamics of entrepreneurship, that is, how they affect the intention, attitude and capacity of university students to initiate the development of a business. In order to answer these questions, we use the psychological theory, Model of Planned Behaviour (Azjen, 1991, 2002), to study the linkages between educational experiences (including curricular and extracurricular activities) and the motivational processes, analysing their effect on university students' attitude, behavioural control, entrepreneurial intention, and entrepreneurial competences (Fayolle et al., 2006; Souitaris et al., 2007). Most of the studies carried out with Azjen's model have used populations of university students (e.g., Alexei and Kolvereid, 1999; Boissin et al., 2009a, b; Karanja et al., 2012; Shinnar et al., 2009; Souitaris et al., 2007; Liñan and Chen, 2009; Venciana et al., 2005), which allow us to contrast our results.

This research makes two main contributions to the interface between university studies and entrepreneurship. First, the study adds significant empirical knowledge to the limited 
understanding of how curricular and extracurricular activities affect the formation of entrepreneurial competences, and of how curricular features influence the entrepreneurial decision process, that is in the attitude, capacity and intention for entrepreneurship. Second, based on the results, a number of implications for policy-makers and universities are drawn regarding how they might plan entrepreneurial training programmes for graduates in Marketing, Business, and Design. In the next section, we present a concise overview of the relevant literature on Higher Education in relation to Entrepreneurship, and our proposed hypotheses. Section three describes the research methodology, including data collection, and measures. Our data analysis and results are provided in section four. Section five presents the discussion and conclusions, as well as limitations and suggestions for future research.

\section{BACKGROUND}

\section{Higher Education and Entrepreneurship}

The relationship between University and entrepreneurship has been a source of debate over the years, a by-product of the significant role that universities should play in their students' entrepreneurship vocation (Trow, 1989; Holmgren et al., 2005; Collins et al., 2005; Ertuna et al., 2011). A first question debated in the literature has been focused on determining whether entrepreneurship initiative can really be taught (Aldrich and Martinez, 2001; Baron, 2002; Bird, 1989; Gartner, 1989; Booth et al., 2009; Nicolau and Shane, 2009). While, on one hand it is assumed that entrepreneurship behaviour is genetically established, on the other hand, it is explained that entrepreneurship behaviour is shaped from experience and interaction with one's surroundings, making it a matter of learning (Aldrich and Wiedenmayer, 1993; Baron 2002; White et al., 2006). The theorists solved the dilemma based on the premise that entrepreneurship has two sides: 'science' and 'art' (Jack and Anderson, 1998; Rae, 2005). Science governs the functional skills of the corporate management, while art involves creative and innovative thinking. In this context, Hills et al. (1988), Versper (1982), Anderson et al. (2008), and Hill et al. (2003), agree that core competences implied in entrepreneurial behaviour can be developed in education regulated backgrounds. For Gibb (1993) this means the beginning of a wide range of activities directed towards the greater development of the students, the faculty and staff.

Laukkanen (2000) proposes the creation of an educational system based on creating entrepreneurship-related competences. He considers that the development of entrepreneurial 
initiative responsibility should not be limited merely to the inclusion of subjects related to entrepreneurship (such as starting a businesses or making business plans) within the curricular contents of the different degrees. Laukkanen (2000) also shows the need to develop an educational route focused on the development of individual competences, with a model of business generation which can create the necessary conditions for starting a business. Following this, Collins et al. (2004), Liñan (2007), Souitaris et al. (2007) and Fayolle and Gailly (2013) propose a model of education combining organized education with the university's institutional support. They identify two components: first, a curricular one, associated with the required coursework in the different degrees, focused on the development of competences; and a second extracurricular component, related to those actions developed through awareness, entrepreneurial support and/or aid. This institutional support resources to promote entrepreneurship initiative are extracurricular actions implemented by the university, aimed at giving proper support to interests and intentions to start a business. Institutional support or extracurricular activities can be classified as cognitive-emotional support, aimed at entrepreneurship culture awareness; informative-formative support, oriented towards providing information and enterprise competences; and instrumental support, designed to provide resources and physical help for the materialization of entrepreneurship intention. In this last case there are initiatives, such as business incubators, which provide knowledge support and specialized counselling for business start-ups as well as space and material resources in very advantageous economic conditions.

A second question discussed in the literature has been what to teach, and how and when to do it. One of the most common actions related to What to teach in the field of entrepreneurship has been to include subjects related to entrepreneurship and Business start-ups in Business and Marketing degrees. In some cases these subjects make up more than $25 \%$ of the degree credits (Laukkanen, 2000; Nabi and Holden, 2008). Nevertheless, this type of training only reaches a limited number of university students, so little by little entrepreneurial training is being included in engineering and design degrees whose creative competences and product knowledge are greater than in other degrees, which means greater entrepreneurial potential (for entrepreneurship actions in Engineering, Design and Music, see Comisión de las Comunidades Europeas, 2005). A related issue under debate is whether these curricular activities should differentiate their contents for Business or non-Business disciplines. Souitaris et al. (2007) feel that while the contents should be similar, the way they are presented should differ, applying a more practical approach 
and taking into consideration that these students need to have basic notions of economics, marketing and administration. Another action has been the creation of programmes exclusively aimed at entrepreneurship (Bachelors and Masters), together with specific short courses for university students and potential entrepreneurs as well as for working entrepreneurs.

Regarding How to teach, there are many strategies and methodologies which are being implemented to varying extents. Thus, Jamieson (1984) has divided entrepreneurial education into three classes: i.e. education about, for, and in enterprise; while Herrmann et al. (2008, p. 21) have argued that in entrepreneurial education there should be 'a shift from transmission models of teaching (learning 'about') to experiential learning (learning 'for')' in order to 'offer students techniques that can be applied in the real world'. In the same line of criticism, Henry et al. (2003, pp.92-3) point out that entrepreneurial education is teaching about enterprise, not for enterprise, which refers to 'preparation [. . .] for a career in self-employment'. For this reason there is an increase in interactive teaching methods which encourage active self-learning and action oriented pedagogy, combined with group work and project-based learning. In this context, Pittaway and Cope (2007), highlight different teaching methods for 'entrepreneurship': action learning (Leitch and Harrison, 1999); new venture simulations (Clouse, 1990; Kelmar, 1992); technology-based simulations (Hindle, 2002; Low et al., 1994); development of actual ventures (Haines, 1988); skills-based courses (Ulijn et al., 2004); video role plays (Robertson and Collins, 2003); experiential learning (Daly, 2001); mentoring (Stewart and Knowles, 2003); design-based learning (Shane and Venkataraman, 2000); and reflective practices (Schön, 1987).Some institutions and experts have even begun to question the profile of the educator who must combine the capacity for teaching with greater professional or business experience (Comisión de las Comunidades Europeas, 2005).

Regarding the third question, When to teach, there is little consensus as to whether an entrepreneurial education should be acquired while the student is still at university or when they have started working. Some studies show that short courses aimed at potential or working entrepreneurs are more effective than undergraduate university courses (Laukkanen, 2000; McLarty, 2005; Saarinen and Ursin, 2012). Moreover, there is a great deal of criticism aimed at the entrepreneurial education received at universities based on the orientation of the teaching, the methodology used and the lack of infrastructure to support student entrepreneurs (Laukkanen, 2000; Gibb, 1993; Souitaris et al., 2007). Here, the criticism also implies that while universities 
are able to foment entrepreneurial intention, transforming this intention into reality means having to overcome at times the elevated costs of transaction and opportunity (Robinson and Sexton, 1994; Pittaway and Cope, 2007). Nevertheless, one argument in favour of entrepreneurial education at university is that it has greater scope than specific post graduate courses and can reach a potentially larger population. Universities themselves, conscious of these deficiencies are developing a series of actions to address the issues. One plan of action aims to foment extracurricular activities, trying to change entrepreneurial intentions into reality. A second group of actions focuses on the development of specific courses for students and potential entrepreneurs, characterized by greater flexibility than that of the more rigid undergraduate programmes, which encourage the acquisition of both knowledge and skills. In this sense there are very interesting and highly effective initiatives among the Executive Education activities in some institutions (Gibb, 1993; Shinnar et al., 2009; Wu and Wu, 2008).

\section{The effectiveness of entrepreneurial training: Hypothesis}

\section{i) Curricular effect on entrepreneurial competences}

The notion of "competency" has received considerable attention in recent years across a diverse mix of fields and domains, including human resource management, education, psychology, strategic management, and public policy (e.g., Bergevoet and Van Woerkum 2006; Hartle 1995; Klein 1996; Shook et al. 2003). Morris et al. (2013, p.353) state that 'competency refers to the knowledge, skills, attitudes, values, and behaviours that people need to successfully perform an activity'. These requirements may form one of the basic differentiating factors between entrepreneurs and other people. A successful entrepreneur is both a creator and an implementer, someone who not only dreams of new things, but is also willing to work hard in order to achieve them (Comisión de las Comunidades Europeas. 2005). Entrepreneurship requires numerous competences that are difficult to define as individual atomic subjects, so while a specific business requires subject specific skills, psychological and social skills lie at the heart of entrepreneurial competence (Morris et al., 2013). These Authors propose a series of entrepreneurial competences which can be summarized as leadership and interactive competences (Chandler and Jansen 1992; Colombo and Grilli 2005; Orser and Riding 2003), personality competences (Hood and Young 1993; Vesper and McMullan 1988; Rae, 1997; Chandler and Hanks 1994; McMullan and Long 1990; Mitchelmore and Rowley 2010) and 
knowledge competences (Freel 1999; Hofer and Charan 1984; Smith and Morse 2005).

Regarding the effectiveness of curricular activities on the entrepreneurial competences, Autio et al. (1997), Krueguer and Brazeal (1994) point out that training in entrepreneurial culture is a remarkably effective way to foment favourable competences to start a business. Results confirm that university education has a positive influence on students' perception of the skills and competences acquired to create companies (Liñan and Chen, 2009; Dohse and Walter, 2010). These Authors point out that education encourages entrepreneurial competences; for example, it has an impact on personality characteristics, including the need for personal fulfilment and the tendency towards risk taking, since these characteristics can be considered essential factors that influence the development and accomplishment of the entrepreneurial spirit. Moreover, it impacts on the development of capacities, both general -i.e. leading a group or a project- and specific -i.e. how to develop a strategic plan- which, as Boissin et al. (2009b) pointed out, are basic when dealing with a business project. Sanchez (2013) highlights that the development of educational programmes has a special impact on the personal competencies essential to entrepreneurship, such as risk taking, self-efficacy, and proactiveness. Hence, we can propose:

H1: There is a positive and significant effect between curricular activities and the development of entrepreneurial competences.

\section{ii) Curricular effect on attitudes, behavioural control and entrepreneurship intentions}

The psychological cognitive approach provides a useful perspective from which to analyse the phenomenon of entrepreneurial decision through the study of perceptions and intentions. The conceptual foundation of the psychological processes leading to entrepreneurial intention is based on Shapero and Ajzen' models (Shapero, 1975; Ajzen, 1991). Nabi and Holden (2008) defined entrepreneurial initiative as the individual career guidance and mind-set towards selfemployment. As this definition suggests entrepreneurship arises from deliberately planned behaviour (Liñan, 2008), and involves the interaction of a number of factors (Nabi et al., 2006; Kakkonen, 2012). These factors, which are based on the desire and the feasibility of developing an action, comprise three elements: attitude, subjective norms and behavioural control (Ajzen, 1991).

Our research question looks at how effective universities are in the development of the entrepreneurial intention. Some controversy about this question can be seen in the literature. 
Thus, different studies have found a positive relationship between an individual's educational level and their intention towards entrepreneurship (Cowling and Taylor, 2001; Delmar and Davidsson, 2000; Robinson y Sexton, 1994). Galloway and Brown (2002), in their research with university students, found evidence that participation in courses of business creation was related to the entrepreneurship intentions of the participants. Krueger and Brazeal (1994) suggest that entrepreneurship education should improve the perceived feasibility and desirability of students by increasing their level of knowledge and self-confidence. Souitaris et al. (2007) uphold that the availability of support resources should have an influence on the attitudes that establish the entrepreneurship intention. Peterman and Kennedy (2003) concluded that the inclusion of subjects related to entrepreneurship in the curriculum seems to increase the participants' disposition to entrepreneurship. Nevertheless, there are opposing arguments, as shown by Garavan and O'Cinneide (1994), which explain how training can influence entrepreneurship in a positive or negative way. Laukkanen (2000) claims that traditionally, higher education institutions not only make their students too analytical, overly conscious of the problems and adverse to risks, but they scare their students about starting new business projects. Ronstadt (1984), and Peterman and Kennedy (2003) also insist that, in general, formal education does not encourage entrepreneurial initiative, but rather it leads to conformity and decreases tolerance for ambiguity, lowering students' capacity for creative thinking, and usually it only prepares the students for jobs as employees, suppressing their creativity and entrepreneurial spirit. On the other hand, it creates greater possibilities for employment. Other researchers argue that formal education reduces curiosity and vision and increases risk aversion (Fallows, 1985; Shapero and Sokol, 1982). Therefore, we observe support both for and against the effect of education on the entrepreneurial intention. Hence, we expect to see in some cases an increase in the entrepreneurial intention among the students of the aforementioned institutions, while in others none. Thus, we propose:

Hypothesis2a: The entrepreneurial intention will be positively influenced by the curricular activities in some cases and negatively influenced in others.

With regards to the relationship between higher education and attitudes and behavioural control, empirical evidence suggests - as shown by Krueguer and Brazeal (1994) - that entrepreneurial education improve university students' attitudes and capacity to start a business. Several Authors point out that education encourages entrepreneurial attitude affecting on 
personality characteristics of students such as autonomy, authority and self-realisation (Galloway et al., 2005; Hartshorn and Hannon, 2005; Wu and Wu, 2008; Liñan and Chen, 2009; Souitaris et al., 2007; Dohse and Walter, 2010). Therefore, the training programmes should develop competences in order to establish entrepreneurial attitudes. Moreover, Laukkanen (2000), Souitaris et al. (2007), Frank et al. (2007), and Fayolle and Galliy (2013) report that an education focused on skills develops university students' capacity to guide a team, solve conflicts, and make decisions. Similarly, an education in business creation reinforces some traits such as the elaboration of a business plan and, as highlighted by Boissin et al. (2009), facilitates the creation of their own business. Likewise, an education focused on the development of projects will foster the behavioural control of university students, generating confidence when they develop their entrepreneurial activity. Therefore, we propose:

H2b: There is a positive and significant effect between curricular activities and attitudes on the development of an entrepreneurial project.

H2c: There is a positive and significant effect between curricular activities and behavioural control on the development of an entrepreneurial project.

As shown in the proposed hypothesis, education in entrepreneurship reinforces the attitude of the university student (Ertuna and Gurel, 2010; Davey et al., 2010). Kolvereid (1996) and Krueger (2000) have pointed out that attitude is directly related to entrepreneurial intention, and thus a combination of education and entrepreneurial attitude will have a positive incidence in entrepreneurial intention. Therefore, we propose:

H2d: There is a positive and significant joint effect between curricular activities and attitudes on entrepreneurial intention.

Curricular activities reinforce the behavioural control of university students and as Kolvereid (1996) and Krueger (2000) explained, behavioural control has a positive and significant impact on entrepreneurial intention, thus, a combination of curricular activities and students' behavioural control will increase their entrepreneurial intention. Therefore, we propose:

H2e: There is a positive and significant joint effect between curricular activities and behavioural control on entrepreneurial intention.

iii) Extracurricular effect on attitudes, behavioural control and entrepreneurship intentions

Regarding the question of the effectiveness of the extra-curricular activities on the fostering of the entrepreneurial intention, we can find different and controversial arguments on the literature. 
Thus, following the studies of the impact of higher education on entrepreneurial intention, Laukkanen (2000), Collins et al. (2004), Fayolle et al. (2006), Souitaris et al. (2007), and Liñan (2007) point out that the extra-curricular activities such as business incubators, information centres and financial aid, are incentives to the entrepreneurial intention. In this way, Laukkanen (2000), and Ramussen and Sorheim (2006) support that the existence of an informational and institutional support, and an adequate entrepreneurial culture encourage university' students to create their own business. However, Coduras et al. (2008), Nabi et al. (2006), and Peterman and Kennedy (2003) emphasize that this supporting activity alone does not encourage entrepreneurial activity; rather it has a neutral effect on university students. Therefore, we observe support both in favour of and against the effect of extra-curricular activities on entrepreneurial intention. Hence, we expect in some cases an increase in the entrepreneurial intention among the students, while in others none. Therefore, we propose:

Hypothesis 3a: The entrepreneurial intention will positively influence the extra-curricular activities of some cases and negatively influence others.

In addition to instruction in entrepreneurship culture, Souitaris et al. (2007) Fayolle et al. (2006) uphold that the availability of support resources also influences the attitudes that establish entrepreneurship intention and behaviour, because access to these resources can stimulate students to view business creation as a desirable and feasible professional option. Thus, it has been proved that activities such as business incubators and information centres have a positive impact on entrepreneurship attitude. This impact is sometimes seen indirectly through desirability and feasibility (Kolvereid, 1996; Tkachev and Kolvereid, 1999; Krueger et al., 2000). Moreover, academicians often emphasize the idea that the established sides of institutional culture (e.g., the type of student-teacher relationship, disciplinary codes, work climate, the institution's 'tradition', as well as expectations cast on the students) represent real, formative messages with the capacity to influence university students' entrepreneurship attitude. In this sense, Souitaris et al. (2007), and Shinnar et al. (2009) discuss the importance of the 'hidden curriculum' for business creation attitude. Moreover, we can consider that extracurricular activities may help and support university students in overcoming the obstacles in the creation of businesses. Wang et al. (2011), Boissin et al. (2009a), Collins et al. (2004), and Autio et al. (2001) argue that infrastructure and financial support are two of the main obstacles faced by a university student in the process of creating a business. Thus, the design of extra-curricular 
activities will foster students' capacity in the process. Hence, we propose:

H3b: There is a positive and significant effect between extracurricular activities and attitudes on the development of an entrepreneurial project.

H3c: There is a positive and significant effect between extra-curricular activities and behavioural control on the development of an entrepreneurial project.

As previously discussed, the aim of extra-curricular activities is to trigger entrepreneurial culture, provide informative-formative support as well as instrumental support to develop an entrepreneurial project. These activities help to foster students' attitude when carrying out their own business project by involving them in an entrepreneurial culture, which has an immediate connection with students' competencies such as autonomy, authority and challenge. Thus, we can expect the combination of extra-curricular activities and entrepreneurial activity to increase the probability of entrepreneurial intention. Therefore, we propose:

H3d: There is a positive and significant joint effect between extracurricular activities and attitudes on the development of an entrepreneurial project and entrepreneurial intention.

Kolvereid (1996), Krueger and Carsrud (1993), and Krueger et al. (2000) argue that behavioural control has a positive incidence in entrepreneurial intention, and thus, we can expect that a combination of extracurricular activities and behavioural control will have a positive impact on university students' entrepreneurial intention. Therefore, we propose:

H3e: There is a positive and significant joint effect between extracurricular activities and behavioural control on the development of an entrepreneurial project and entrepreneurial intention.

\section{METHODOLOGY}

As we pointed out in the introduction, an empirical study was carried out using a convenience sample based on two Spanish institutions. Spain has a long tradition of entrepreneurial activities as well as a growing trend in the development of university entrepreneurship programs. For example, Dalmau et al. (2003) report that in the year 2003, 54.4\% of the 68 universities were offering entrepreneurship programs. However, these authors point out that despite progress, entrepreneurship is still a pending issue for Spanish universities. In 2012, 79 Spanish universities (public and private) had specific programs aimed at entrepreneurship.

The first institution - ESIC Business and Marketing School - is a business school with 4500 
students, offering undergraduate Degrees in Business and Marketing. ESIC teaching is characterized by its highly developed and well tested curricula in the area of entrepreneurship, both in subject matter as well as methodology. It also offers an extensive selection of extracurricular activities to encourage entrepreneurship, such as entrepreneurship awards, business incubators, an entrepreneurial training and information centre, etc. The second case in our study corresponds to ESNE - University School of Design, Innovation and Technology - an institution that has developed a grouping of new undergraduate degrees: Interior Design, Multimedia and Graphic Design, Fashion Design, and Videogames Design and Development, with a total of 950 students, highly oriented to the development of self-employment and entrepreneurship.

To obtain our data, a questionnaire was distributed to the different groups during class. All the questionnaires were given in the same week in May of 2013. A total of 950 valid questionnaires were obtained from ESIC and 525 from ESNE. The questionnaire was tested on 20 students from different courses and degrees.

The possibility of non-answer bias in both cases was verified by comparing polled students' characteristics with those of the objective sample of the population by means of a t-test and ANOVA among the different groups of answers (Armstrong and Overton, 1977). There were no significant differences among the groups of answers by courses or degrees.

\section{Measures}

In our study, the measure of intention, attitude, and behavioural control variables, has been adapted from Kautonen et al. (2015), and Kolvereid (1996) which conceptualized these variables as perceived dimensions. Thus, we measured all items referring to the same behaviour (engaging in activities to start a business) and the same time frame (within the coming 12 months). The different measures addressed the following questions in each case: (1) Intention, 'I intend to take steps to start a business in the next 12 months'; (2) Attitude, 'For me, taking steps to start a business in the next 12 months would be unpleasant/attractive'; (3) Behavioural control, 'If I wanted to, I could take steps to start a business in the next 12 months'. Each construct was measured using a seven-point Likert scale.

The curricular activities were conceptualized by referring to student participation in formal learning situations involving the teaching of abilities and attitudes related to entrepreneurship 
competences, as defined by the European Reference Framework on Key Competences for Lifelong Learning (Recommendation 2006/962/CE, section 2.2.1). To evaluate the influence of the courses, students were asked about the curricular activities that most influenced their current entrepreneurial motivation. Thus, following Laukkanen (2000), Souitaris et al. (2007), and McLarty (2005) students were asked to rank the following items: 1) the courses given in their degree program related to entrepreneurship; 2) coursework and practicums; (3) the role of the teacher; 4) the use of case studies in class; 5) the realisation of group work; 6) talks or lectures by entrepreneurs; and 7) teaching methodology related to entrepreneurship. Each construct was measured using a seven-point Likert scale (Cronbach alpha: 0.766).

The extracurricular activities variables were conceptualized also as perceived dimensions, that is, the contextual influences in the configuration of entrepreneurship intention. Thus, following Ramussen and Sorheim (2006), De Faoite et al. (2003), and Potter (2010), we measured extracurricular activities as the support for cognitive, informative/formative, and instrumental actions for the materialisation of entrepreneurship intention. We adapted from these Authors the following items: 1) Conferences and seminars dedicated to entrepreneurship; 2) visits to businesses; 3) Business simulators/games; 4) entrepreneurial projects; 5) Facilities and infrastructures for entrepreneurship; and 6) entrepreneurial spirit and values transmitted by the university. Each construct was measured with using a seven-point Likert scale (Cronbach apha: $0.710)$.

Following Sanchez (2009); Rasmussen et al. (2011); Morris et al. (2013), we measured competences of interaction (decision-making, leadership, and teamwork), psychological competences (concentration, analysis, initiative, tenacity, creativity, self-confidence, and risk) and competences of knowledge. We asked students to rank the following items: 1) Decisionmaking capacity in my business plan; 2) Effort and concentration to be successful; 3) Capacity to analyse several solutions and take the most appropriate decision; 4) In group work situations I can identify the skills of each person and can ensure that they complement each other by creating an atmosphere of collaboration; 5) Capacity to take the initiative, define goals; 6) I work as much as necessary to finish a project; 7) I propose new ways of doing thing; 8) Self-confidence; 9) Leadership, ability to convince and bring other people into my project. Each construct was measured using a seven-point Likert scale. 


\section{Control Variables}

Because in this study the intention variable may be influenced by other factors outside this model (Azjen, 1991; 2002), eight additional variables were incorporated: Sex, Population Size, Age, Higher School, Year, Parents' Education, Parents'Work, and Experience of university students (Kolvereid, 1996; Krueger, 1993; Krueger and Brazeal, 1994; Guerrero et al., 2008). For these variables, we used a Likert scale from 1 (low) to 7 (high), and asked students to indicate their level of agreement with the statements.

\section{ANALYSIS AND RESULTS}

Table 1 shows the statistical data of the profile of an entrepreneurial university student for both cases studied. We may highlight that out of a sample of 1475 students, an entrepreneurship attitude is found in nearly two-thirds of the students both in ESIC as well as in ESNE (60.7\% and $61.5 \%$ in each case); compared to these results, the capacity and intention to develop an entrepreneurial project in the next 12 months shows much lower values (capacity: 35.6\% and 18.9\%; intention: $21.0 \%$ and $15.5 \%$, in the case of ESIC and ESNE respectively). These results corroborate those of other studies thus highlighting the difficulty of actually putting a business plan into practice as opposed to merely being motivated to do so (Nabi and Holden, 2006; Liñán, 2008; Boissin et al., 2009a, b). This also clearly shows the limitations and lack of effectiveness of extracurricular activities in motivating and supporting students in the development of entrepreneurial projects. Likewise, the results show the different effect that curricular activities have on motivating and preparing students to carry out an entrepreneurial project. Moreover, our results show that, by gender, the disposition to start their own business is slightly greater among men; regarding age, among 18 to 25 year olds there is no significant age profile where entrepreneurship tendency is remarkably noticeable. However, we saw a slight decrease in entrepreneurship attitude as students progressed in their degrees. These results corroborate previous ones found in the literature on entrepreneurs, related to the discouraging effect that education has on the incentive to start a business (Boissin et al., 2009a). However, these findings contradict other research indicating that the proximity to the completion of studies is reflected in an increase of entrepreneurial intention (Autio et al., 1997; Boissin et al, 2009b). Our results may be due to undergraduate university training, which is still "on" entrepreneurship and not "for" entrepreneurship (Coduras et al., 2008). Moreover, parents' educational level influences 
student entrepreneurship vocation very favourably; those university students who showed the most favourable attitude towards starting their own business were those whose parents have university and/or postgraduate studies. Moreover, the interest in developing business activities on their own is greater in students whose parents already own a business. One last factor, job experience, allows us to see that entrepreneurship motivation has a greater presence among students who have had some work experience than among those who had not.

Insert Table 1 about here

Regarding our first questions whether curricular activities have a significant effect on the competences needed for students in setting up a business, our results show that in the case of ESIC, the effect of curricular activities on competences is heterogeneous. We thus observe (see Table 3) that the knowledge needed to set up a business is acquired especially through course content $(\beta=0.223, \mathrm{p}<0.05)$, teaching $(\beta=0.214, \mathrm{p}<0.05)$, and case studies $(\beta=0.175, \mathrm{p}<$ 0.10 ), whereas, curricular activities such as case studies, group work and practicums show to have a significant effect on the competences of interaction (leadership, decision-making and groups work). Personality and psychological competences however show different effects. Thus we observe that the competences most affected by curricular activities are those of concentration, analytical skills and confidence; to a lesser degree competences such as tenacity, creativity and risk assumption. The results of the analysis also show that Modules and Coursework have a positive effect on analytical capacity $(\beta=0.119, \mathrm{p}<0.10 ; \beta=0.295, \mathrm{p}<0.05)$, and concentration $(\beta=0.256, p<0.05 ; \beta=0.110, p<0.10)$. Cases studies worked in class have a positive effect on the capacity for analysis $(\beta=0.117, \mathrm{p}<0.10)$ and initiative $(\beta=0.133, \mathrm{p}<0.10)$; finally, group work stimulates analytical capacity $(\beta=0.301, \mathrm{p}<0.05)$. The confidence to develop a business plan is positively affected by teachers $(\beta=0.211, \mathrm{p}<0.05)$, group work $(\beta=0.319, \mathrm{p}<0.05)$, and conferences on entrepreneurship $(\beta=0.182, \mathrm{p}<0.10)$. Students' perception of the teaching methodology is that it fundamentally develops concentration and knowledge, as shown by the positive effect of teaching on these two competences. These results in turn also highlight the pedagogical weakness of curricular activities in the development of entrepreneurial competences. Likewise, they corroborate the need to include skills acquisition in curricular activities, especially in the development of the psychological characteristics of an entrepreneur, and in the development of interaction competences (Laukkanen, 2000). 
In the case of ESNE, we have observed that the effect of curricular activities on competences is different in comparison to the case of ESIC (see Table 5). One of the first aspects observed is that the teaching methodology has a positive effect on creativity $(\beta=0.220, p<0.10)$, analytical capacity $(\beta=0.107, \mathrm{p}<0.05)$, as well as student confidence $(\beta=0.139, \mathrm{p}<0.10)$. Another differentiating aspect is that the contents of the modules, as well as the practicum, have a positive and significant effect on personality competences. Thus, education in design in its different facets - software or fashion - foments the competences of creativity, self-confidence, tenacity and risk, as well as those of analysis, concentration and initiative. Moreover, the role of the teacher is different. Whereas in the case of ESIC the teacher is a transmitter of knowledge, in ESNE, he or she develops the competences of leadership in the student $(\beta=0.193, p<0.10)$, as well as aiding in the decision to start a business $(\beta=0.107, p<0.10)$. An analysis of the teacher profile shows that at ESNE a high percentage of teachers have their own business, they are entrepreneurs. These results provide empirical evidence pointing out the importance of the participation of entrepreneurs in university teaching, transmitting their real life experiences (Comisión de las Comunidades Europeas, 2005). Additionally, conferences and seminars have a similar effect in both cases studied, helping to develop analytical competences $(\beta=0.110, p<$ $0.10)$, and confidence $(\beta=0.250, \mathrm{p}<0.05)$.

\section{---------- Insert Tables 4 and 5 about here}

Regarding the influence of curricular and extracurricular activities on entrepreneurial intention, Tables 8, 9 and 10 show the results of our estimations of the causal effect of the variables affecting entrepreneurial intention in both institutions. First of all, our results display an explained variance between 0.23 to 0.45 . Our results follow the line of previous studies applying Azjen's model (Kolvereid, 1996; Tkachev and Kolvereid, 1999; Krueger et al., 2000; Kolvereid, 1996), which allows us to accept the explanatory validity of our model. Moreover, for both of the studied cases, we observe a positive and significant influence of attitude ( $\beta=$ $0.352, \mathrm{p}<0.05 ; \beta=0.211, \mathrm{p}<0.10)$ and behavioural control $(\beta=0.182, \mathrm{p}<0.10 ; \beta=0.195, \mathrm{p}<$ 0.10 ) on entrepreneurial intention. These results are similar to other results obtained in previous research where these two variables are shown as an explanation of entrepreneurial intention (Kolvereid, 1996; Tkachev and Kolvereid, 1999).

$$
\text { --------- Insert Tables 6, 7, 8, 9, and } 10 \text { about here }
$$

In Table 8, our results show a positive impact of higher education in the model's explanatory 
variables for the case of ESIC. Thus, we observe that both curricular $(\beta=0.351, p<0.01)$, and extracurricular $(\beta=0.311, \mathrm{p}<0.05)$ activities have a positive effect on entrepreneurial attitude. However, in the case of ESNE, while we find a positive effect of curricular activities on attitude $(\beta=0.150, \mathrm{p}<0.10)$, this is not the case of extracurricular activities. With regards to behavioural control, and following the same line as the variable attitude, it can be observed that both types of activities have a positive impact in the case of $\operatorname{ESIC~}(\beta=0.394, p<0.01 ; \beta=$ $0.160, \mathrm{p}<0.10)$. This finding supports our Hypotheses $2 \mathrm{~b}$ and $2 \mathrm{c}, 3 \mathrm{~b}$ and $3 \mathrm{c}$. These data are similar to other studies (Laukkanen, 2000; Souitaris et al., 2007) that emphasize how curricular and extracurricular activities have a direct impact on both the formation of an entrepreneurial attitude, and on the capacity to develop a business project.

Regarding the impact of the university itself on entrepreneurial intention, the results are shown in Tables 9 and 10. Table 9 displays the results for the case of ESIC, where neither curricular nor extracurricular activities have any impact on entrepreneurship intention. These results are in line with previous studies showing that university students do not perceive university education as having a direct effect on business creation (Ertuna and Gurel, 2010). Fayolle and Gally (2013) point out that university students find it unlikely that they will create their own business; moreover, even though in their ideal job they would do so, in the short run they tend to work as organisational-employed. Bosissin et al. (2009b) highlight the disincentive effect of university education, demonstrated by the diminishing of the entrepreneurial intention as the number of years of education increases. However Hypothesis $2 \mathrm{~d}$, and $2 \mathrm{e}, 3 \mathrm{~d}$, and $3 \mathrm{e}$ are supported and we can observe a synergic and complementary effect of attitudes and behavioural control, with education and extracurricular activities, and their impact on entrepreneurial intention. These data confirm previous studies in which attitude, and the control of university students' behaviour, combined with an entrepreneurial education and supporting infrastructure were found to have a positive impact on the entrepreneurial decision to create a business (Fayolle et al., 2006; Smith et al., 2006; Thompson et al., 2010; Guerrero and Urbano, 2012; De Silva, M. 2015).

\section{DISCUSSION AND CONCLUSIONS}

When comparing the entrepreneurial intention with the current outcome, only about $4 \%$ of college students participate in entrepreneurial work in ESIC and around 7\% in ESNE, it becomes 
clear that it is necessary to activate the dynamic role of university in the promotion of entrepreneurship among university students. These data confirm the low participation of university students trained in entrepreneurship in any form of self-employment (Autio et al., 1997; Peterman and Kennedy, 2003). Furthermore, the results show that the technological and design degrees have a higher percentage of students engaged in start-up enterprises than traditional degrees on Business and Marketing (Souitaris et al., 2007). In this regard, Souitaris et al. (2007) note that in general, innovative and viable business ideas arise from technical, scientific and creative studies. Thus, students in disciplines such as technology, art or design usually are very good at the technical and creative level, and often have very solid ideas in products or services. This is a result of the type of education received; much aimed at obtaining products and services, which, together with a faculty in which entrepreneurs are abundant, makes the development of entrepreneurship among these students very natural (Enterprise and Industry Directorate-General, 2008). The results of the present study conclude that university students' capacities and attitudes have a very significant influence on their entrepreneurship intention, whereas less influence is seen of education in the university context or extracurricular activities. A noteworthy point is the moderating nature of both university education and extracurricular activities in the development of entrepreneurial intention, as shown in our results, through the creation of attitudes and the increase in behavioural control (Kolvereid, 1996; Krueger et al., 2000; Tkachev and Kolvereid, 1999). Moreover, our results have shown that curricular and extracurricular activities have an unequal effect on university students. University training is achieving high levels in attitude towards entrepreneurship and the creation of businesses, but low levels in capacity and entrepreneurial intention. Therefore, a first conclusion derived from these results suggests that institutions of higher education need to make greater efforts to improve the levels of training, and to encourage an entrepreneurial attitude. This can lead to an increase in the level of intention which, along with the adequate extracurricular measures and student support during the process, can facilitate the development of start-ups.

Another unequal effect is produced between curricular activities and competences, as our results show. A second conclusion to be drawn from this suggests that higher education institutions should contribute as much to the development of capacities of interaction as to psychology and knowledge. Thus we see that in the case of Marketing and Business degrees, students lack the development of psychological and personality competencies. In the case of 
Design students, we see a lack of business knowledge, and development of interactive competences. In general terms, it is assumed that learning the basic competences and specific knowledge of new business start-ups requires that different teaching methodologies and strategies be complemented with knowledge of marketing and business. In this sense Laukkanen (2000), and Carolis and Saparito (2006) propose a series of pedagogical measures such as: not overusing theory-based methods, developing autonomous learning, fomenting learning based on action and direct participation of the student, providing learning opportunities based on experience, facilitating cooperative and interactive learning, and not underestimating the role of support. Thus, a methodological and strategical change in education would be recommended to encourage the development of entrepreneurial competences.

Therefore, based on the results of this study, we present a series of proposals for policy makers and universities. In the first place, curricular activities should develop 'action' programmes; that is, programmes which stimulate the search for opportunities and acquisition of 'action' abilities. In this sense, De Carolis and Saparito (2006), and Saarinen and Ursin (2012) propose the development of programmes to encourage learning based on problems and projects, a characteristic of learning-by-doing education. In this way, Laukkanen (2000) points out some needed tools in business activity, such as analysis and problem-solving, interpersonal skills, negotiation or conflict resolution techniques, among others. As a result of competence development, the methodology used in education should be based on the work of the students and their own personal development, and not on the educator's work alone. Specifically, it is felt that a project-based learning methodology (Hanke, 2009) is highly suited for developing the competences closely related to those needed in entrepreneurship, such as: the search and structuring of information, group work, autonomous learning, time management and project work, and the capacity to express one's self correctly. Similarly, methodology based on Problem Based Learning (PBL) highlights that students must assume responsibility for their own learning. Thus the problems posed to them must be intentionally unstructured and allow for free interpretation in order to promote competences of self-efficacy and proactivity. Also, the subjects and activities must be related to the real world and contribute the values needed in professional and social situations, and include cooperative group work, collaborative learning and responsibility. All of which comprise essential competences in the work place.

In the second place, innovation is mainly a result of teaching methods oriented towards action 
and based on student participation in multidisciplinary groups. In this way, the development of group techniques and group work to conceive new business ideas, as well as creating mixed groups of students from business studies with those from non-business studies are key elements for the emergence of new ideas. We have seen, in design degrees, for example, that creativity and product knowledge form the basis of learning, whereas in business and marketing degrees, knowledge is centred on creating a business. Activities for developing business plans should be based on ideas from real businesses and, in this sense, Decramer et al. (2012) point out that a greater participation by businesses and business people, as well as a more extensive use of methods based on case studies and specific projects, are better suited to develop innovation.

A third proposal suggests that educators should be, to a certain extent, entrepreneurs and their teaching should be based on experiences drawn from real life. Students perceive this type of teaching quite differently from that of traditional learning experiences in higher education because it breaks down the boundaries between university and the outside world.

From a review of the literature, we have observed that the most successful courses invariably have a common characteristic: flexibility (Fayolle et al., 2006; Enterprise and Industry Directorate-General, 2008). Thus, a fourth proposal would be the need to design more flexible courses: in terms of practicum periods, being able to alternate between part-time and full-time study, and the organization of intensive courses.

To sum up, classic curricular activities based on contents and teaching need to incorporate group activities and teamwork to conceive new business ideas; business plan workshops that allow students to maximize the development of innovative ideas; and case studies which expose students to easily identifiable behavioural models. Bringing in guest speakers, especially business people and entrepreneurs, and using business simulators to teach the inner dynamics and workings of companies comprise activities which greatly favour the transformation of students into entrepreneurs.

Our fifth proposal regards the need to incorporate formative contents into degrees other than the traditional Business and Marketing programmes. To do this, and following Souitaris et al. (2007), the majority of possible course contents related to entrepreneurial initiative are applicable to students in all areas of study. Nevertheless, there should be some specialisation in one particular aspect or another so that the contents can be adapted to the specific needs of different study plans and student needs. Thus, in technical and scientific programmes, the 
entrepreneurial initiative should focus on the exploitation of intellectual property, the creation of spin-offs, offering courses on administration, marketing, advertising and sales of technologically based ideas; patents and protection of technologically based ideas; financing and internationalisation of high-tech business activities. In the studies of art and design, the focus should be on opportunities derived from creativity and creative work, preparing graduates to work freelance or be self-employed, to set up small companies or engage in other entrepreneurial activities.

Regarding extracurricular activities, these should allow students to search for business opportunities as well as to provide suitable support with which to develop them. From our study it can be seen that the main contribution of extracurricular activities is that of transforming intentions into projects. To do this, these activities should contain some fundamental aspects, such as the development of information centres, and infrastructure and material resources to ensure that the university becomes an 'entrepreneurial university'. According to Guerrero and Urbano (2012), an entrepreneurial university 'is an instrument that not only provides a workforce and added value with the creation or transformation of knowledge, but also improves the individual's values and attitudes towards these issues' (Guerrero and Urbano, 2012. p. 55). In this sense, the university should develop strategies, structures and a culture oriented to reinforcing the creativity and entrepreneurial experience and strategies for entrepreneurial incentives, along with strong collaborative agreements between university and industry.

Like all studies, this one has certain limitations that further research should overcome. The study covered generic response among Business and Marketing, and Design undergraduate students; the results may differ if other streams like Computer Science, Information Technology and Engineering are incorporated. Therefore, it may be interesting to identify the different entrepreneurial intentions and reasons for such orientation. On the other hand, our research only covered two institutions; it is required to expand the research findings to other universities and institutions within the country and abroad. Finally, since the analysis is built upon cross-sectional data, the long-term effects of the attitudes, capacities and intentions could not be investigated.

These conclusions and limitations suggest proposals for future research direction. First, explore other dimensions of the variables and developing new models to assess the incidence of higher education in entrepreneurship intention in a more direct way. Second, pay attention to additional factors that could improve the effect of curricular and extracurricular activities on 
entrepreneurship. Third, a longitudinal study could offer some new insight into the effects of higher education on university students' entrepreneurial intention.

\section{REFERENCES}

Acs, Z J., and Szerb, L. 2007. Entrepreneurship, Economic Growth and Public Policy. Small Business Economics 28(2-3): 109-122.

Acs, Z. J., Arenius, P., Hay, M. and Minniti, M. 2005. Global Entrepreneurship Monitor 2004, Executive Report. Retrieved Badson Park, MA- Londres.

Ajzen, I. 1991. The theory of planned behavior. Organizational Behavior and Human Decision Processes 50: 179-211.

Ajzen, I. 2002. Perceived Behavioral Control, Self-Efficacy, Locus of Control, and the Theory of Planned Behavior. Journal of Applied Social Psychology 32: 1-20.

Aldrich, H. E., and Martínez, M. A. 2001. Many are called but few are chosen: An evolutionary perspective for the study of entrepreneurship. Entrepreneurship Theory and Practice 25(4): 41-56.

Aldrich, H. E., and Wiedenmayer, G. 1993. From traits to rates: An ecological perspective on organizational foundings. In J. Katz and R. Brockhaus (Eds.), Advances in entrepreneurship, firm emergence, and growth, 145-191. Greenwich, CT: JAI Press.

Alexei, T. and Kolvereid, L. 1999. Self-employment intentions among Russian students. Entrepreneurship and Regional Development 11(3): 269-271.

Anderson, A. R., and Jack, S. L. 2008. Role typologies for enterprising education: The professional artisan? Journal of Small Business and Enterprise Development 15: 259-273.

Armstrong, J. S., and Overton, T. S. 1977. Estimating non response bias in mail surveys. Journal of Marketing Research XIV: 396-402.

Ashfod, S. J., George, E., and Blatt, R. 2007. Old assumptions, new work. The opportunities and challenges of research on nonstandard employment. The Academy of Management Annals 1: 65-117.

Audretsch, D. B., Thurik, R., Verheul, I., and Wennekers, S. (Eds.). 2002. Entrepreneurship: Determinants and policy in a European-U.S. comparison. Boston-Dordrecht: Kluwer Academic Publishers.

Autio, E., Keeley, R. H., Klofsten, M., and Ulfstedt, T. 1997. Entrepreneurial intent among students: Testing an intent model in Asia, Scandinavia and USA. Frontiers of 
Entrepreneurship Research, Babson Conference Proceedings. Boston, MA.

Autio, E., Keeley, R.H., Klofsten, M., Parker, G., and Hay, M. 2001. Entrepreneurial Intent among Students in Scandinavia and in the USA. Enterprise and Innovation Management Studies 2(2): 145-160.

Bandura, A. 1977. Self-efficacy: toward a unifying theory of behavioral change. Psychological Review 84(2): 191-215.

Baron, R. A. 2002. OB and entrepreneurship: The reciprocal benefits of closer conceptual links. IN B. Staw and E. Kramer (Eds.), Research in Organizational Behavior, 225-269. Greenwich, CT: JAI Press.

Bird, B. 1989. Entrepreneurial behavior. Glenview, IL: Scott, Foresman and Company.

Boissin, J.P., Chollet, B., and Emin, S. 2009a. Les déterminants de l'intention de créer une entreprise chez les étudiants : un test empirique.M@n@gement 12(1):28-51.

Boissin, J.P., Branchet, B., Emin, S., and Herbert, J. 2009b. Students and Entrepreneurship: A Comparative Study France - United States, Journal of Small Business and Entrepreneurship 22(2): 101-22.

BOE, 2013. Ley 14/2013, de 27 de septiembre, de apoyo a los emprendedores y su internacionalización. Boletin Oficial del Estado, Madrid.

Booth, A., McLean, M. and Walkerb, M. 2009. Self, others and society: a case study of university integrative learning. Studies in Higher Education 34(8), 929-939.

Boyd, P. and Smith, C. (2014). The contemporary academic: orientation towards research work and researcher identity of higher education lecturers in the health professions. Studies in Higher Education, (Published online, 29 Jul 2014).

Buckland, R. 2009. Private and Public Sector Models for Strategies in Universities. British Journal of Management 20: 524-536.

Clouse, V. G. H. 1990. A Controlled Experiment Relating Entrepreneurial Education to Students' Start-up Decisions. Journal of Small Business Management 28: 45-53.

Collins, L., Hannon, P.D. and Smith, A. 2004. Enacting entrepreneurial intent: the gaps between student needs and higher education. Education+Training 46(8-9): 454-63.

Comisión de las Comunidades Europeas. 2005. Propuesta de recomendación del Parlamento Europeo y del Consejo sobre las competencias clave para el aprendizaje permanente. Bruselas, 10.11.2005, COM (2005)548 final, 2005/0221(COD). 
Coduras, A., Urbano, D., Rojas, A., and Martínez, S. 2008. The relationship between University support to entrepreneurship with entrepreneurial activity in Spain. International Advances in Economic Research, 16: 395-406

Cotton, J., and Gibb, A. A. 1992. An evaluation study of enterprise education in the North of England. Durham City, UK: Enterprise and Industry Education Unit, Durham University Business School.

Cowling, M. and Taylor, M. 2001. Entrepreneurial Women and Men: Two Different Species? Small Business Economics 16(3): 167-175.

Cranmer, S. 2006. Enhancing graduate employability: best intentions and mixed outcomes.

Dalmau, J. I., Alonso, J. L., and Colomer, J. (2003). Programa IDEAS. Un modelo de éxito para fomentar la creación de empresas desde las universidades. Universidad Politécnica de Valencia. España.

Daly, S. 2001. Student-operated Internet Businesses: True Experiential Learning in Entrepreneurship and Retail Management. Journal of Marketing Education 23: 204-15.

Davey, T., Plewa, C. and Struwig, M. 2010. Entrepreneurship perceptions and career intentions of international students. Education + Training 53(5): 335-352.

Davidsson, P. 1995. Determinants of entrepreneurial intentions. Proceedings of the Conference on RENTIX Workshop, Piacenza, November: 23-24.

De Carolis, D. and Saparito, P. 2006. Social capital, cognition and entrepreneurial opportunities: a theoretical framework. Entrepreneurship Theory and Practice 30: 41-56.

De Faoite, D., Henry, C., Johnston, K., and Sijde, P. V. 2003. Education and training for entrepreneurs: A consideration of initiatives in Ireland and The Netherlands. Education + Training 45: 430-438.

De Silva, M. 2015. Academic entrepreneurship and traditional academic duties: synergy or rivalry?, Studies in Higher Education, DOI:10.1080/03075079.2015.1029901

Decramer, A., Smolders, C., Vanderstraeten, A. and Christiaens, J. 2012. The Impact of Institutional Pressures on Employee Performance Management Systems in Higher Education in the Low Countries. British Journal of Management 23: S88-S103

Delmar, F., and Davidsson, P. 2000. Where do they come from? Prevalence and characteristics of nascent entrepreneurs. Entrepreneurship and Regional Development 12: 1-23.

Dohse, D., and Walter, S. G. 2010. The role of entrepreneurship education and regional context 
in forming entrepreneurial intentions. Documents de Treball de l'IEB 2010/18. Barcelona: Institut d'Economia de Barcelona.

Douglas, E.J. and Shepherd, D.A. 2002. Self-employment as a career Choice: attitudes, entrepreneurial intentions, and utility Maximization. Entrepreneurial Theory and Practice 26(3): 81-90.

Dyer, G. 1994. Toward a Theory of Entrepreneurial Careers. Entrepreneurship, Theory and Practice 19(2): 7-21.

Education and Culture General Direction 2004. Implementation of "Education \& Training 2010”. Entrepreneurship education and training. Brussels: European Commission.

Enterprise and Industry Directorate-General, 2008. Entrepreneurship in higher education, especially in non-business studies. Brussels: European Commission.

Enterprise General Direction 2008. Survey of entrepreneurship in higher education in Europe. Main report. Brussels: European Commission.

Ertuna, Z. and Gurel, E. 2011. The moderating role of higher education on entrepreneurship. Education+Training 53(5): 387-402

European Commission 2007. Panorama of the European labour market. Brussels: Organization Gallup.

Eurostat, 2015. Unemployment statistics. Eurostat Office, Brussels. http://ec.europa.eu/eurostat/statistics-explained/index.php/Unemployment_statistics.

Fallows, J. 1985. The case against credentialism. The Atlantic Monthly, December: 49-67.

Fayolle, A. and Gailly, B. 2013. The Impact of Entrepreneurship Education on Entrepreneurial Attitudes and Intention: Hysteresis and Persistence. Journal of Small Business Management 4: 29-42.

Fayolle, A., Gailly, B. and Lassas-Clerc, N. 2006. Assessing the impact of entrepreneurship education programmes: a new methodology. Journal of European Industrial Training 30(9): 701-720.

Frank, H., Lueger, M. and Korunka, C. 2007. The significance of personality in business start-up intentions, start-up realization and business success. Entrepreneurship \& Regional Development 19(3): 227-51.

Fundación Universidad-Empresa 2012. Educación emprendedora: servicios y programas de las universidades españolas. Madrid. 
Galloway, L., Anderson, M., Brown, W., and Wilson, L. 2005. Enterprise skills for the economy. Education + Training 47: 7-17.

Garavan, T. N., and O’Cinneide, B. 1994. Entrepreneurship education and training programmes: A review and evaluation. Part I. Journal of European Industrial Training 18: 3-12.

Gartner, W.B. 1989. Who is an Entrepreneur? Is the Wrong Question. Entrepreneurship Theory and Practice 13(4):47-68.

Gasse, Y. 1985. A strategy for the promotion and identification of potential entrepreneurs at the secondary school level. Frontiers of Entrepreneurship Research, Babson College,

Gibb, A. A. 1993. The enterprise culture and education. International Small Business Journal 11(3): 11-34.

GEM, 2015. Global Entrepreneurship Monitor: Informe GEM España 2014. Centro Internacional de Emprendimiento, Santander.

Guerrero, M., Rialp, J., and Urbano, D. 2008. The impact of desirability and feasibility on entrepreneurial intentions: a structural equation model. International Entrepreneurship and Management Journal 4(1): 35-50.

Gurel, E., Altinay, L., and Daniele, R. 2010. Tourism students' entrepreneurial intentions. Annals of Tourism Research 37(3): 646-69.

Haines, G. H. 1988. The Ombudsman: Teaching Entrepreneurship. Interfaces 18: 23-30.

Hartshorn, C., and Hannon, P. D. 2005. Paradoxes in entrepreneurship education: Chalk and talk or chalk and cheese? A case approach. Education + Training 47: 616-627.

Hegarty, C. 2006. It's not an exact science: Teaching entrepreneurship in Northern Ireland. Education + Training 48: 322-335.

Henry, C., Hill, F. and Leitch, C. (2003), Entrepreneurship Education and Training. Ashgate, Aldershot.

Hill, S., and O'Cinneide, B. 1998. Entrepreneurship education - case studies from the Celtic Tiger. Proceedings of the Conference on Enterprise and Learning, Aberdeen, Reino Unido.

Hill, S., O'Cinneide, B., and Kiesner, F. 2003. Graduate entrepreneurship education - an international "consumer" study. Proceedings of the Conference on International Council for Small Business. 48th World Conference, Northern Ireland, Ireland.

Hills, G. E., Shrader, R. C., and Lumpkin, G. T. 1999. Opportunity recognition as a creative process. In R. D. Reynolds, W. D. Bygrave, S. Manigart, C. M. Mason, G. D. Meyer, H. J. 
Sapienza, and K. G. Shaver (Eds.), Frontiers of entrepreneurship research, 567-591. Waltham, MA: P \& R Publication Inc.

Hindle, K. 2002. A Grounded Theory for Teaching Entrepreneurship using Simulation Games. Simulation \& Gaming 33: 236-41.

Hindle, K., and Cutting, N. 2002. Can applied entrepreneurship education enhance job satisfaction and financial performance? An empirical investigation in the Australian pharmacy profession. Journal of Small Business Management 40: 162-167.

Hisrich, R. D., and Peters, M. P. 1998. Entrepreneurship. Boston, MA: Irwin McGraw-Hill.

Holmgren, C. and From, J. 2005. Taylorism of the mind: entrepreneurship education from a perspective of educational research. European Educational Research Journal 4(4): 382-90.

Hood, J. N., and Young, J. E. 1993. Entrepreneurship's requisite areas of development: A survey of top executives in successful entrepreneurial firms. Journal of Business Venturing 8: 115135.

Jack, S. L., and Anderson, A. R. 1998. Entrepreneurship education within the condition of entreprenology. Proceedings of the Conference on Enterprise and Learning, Aberdeen, UK.

Kakkonen, M. L. 2012. The relationship between self-perceived generic competences and entrepreneurial intention, Industry and Higher Education 26(3): 217-227.

Karanja, J.N., Ngugi, J., Gakure, R.W. and Kiwara, A.N. 2012. Application of Shapero's model in explaining entrepreneurial intentions among university students in Kenya. International Journal of Business and Social Research 2(4): 125-148.

Katz, J., and Gartner, W. B. 1988. Properties of emerging organizations. Academy of Management Review 13(3): 429-441.

Keeley, R. H. and Roure, J. B. 1990. Management, strategy, and industry structure as influences on the success of new firms. Management Science 36: 1256-1267.

Kelmar, J. H. 1992. Business Plans for Teaching Entrepreneurial Behaviour. Education \& Training 34: 30-42.

Kirby, D.A. 2005. Entrepreneurship education: can business schools meet the challenge?, Proceedings of the 2005 San Francisco-Silicon Valley Global Entrepreneurship Research Conference, San Francisco, CA, 173-93.

Kolvereid, L. 1996. Prediction of employment status choice intentions. Entrepreneurship Theory and Practice 21(1): 47-57. 
Kourilsky, M. L. 1995. Entrepreneurship education: Opportunity in search of curriculum. Kansas City, MO: Centre for Entrepreneurial Leadership, Ewing Marion Kauffman Foundation.

Krueger, N. 1993. The impact of prior entrepreneurial exposure on perceptions of new venture feasibility and desirability. Entrepreneurship, Theory and Practice 18(1): 5-24.

Krueger, N. and Brazeal, D. 1994. Entrepreneurial Potential and Potential Entrepreneurs. Entrepreneurship Theory and Practice, primavera, 91-104.

Krueger, N.F. 2000. The cognitive infrastructure of opportunity emergence. Entrepreneurship Theory and Practice 24(3): 5-23.

Krueger, N.F. and Carsrud, A. 1993. Entrepreneurial Intentions: Applying the Theory of Planned Behavior, Entrepreneurship and Regional Development 5: 315-330.

Krueger, N.F., Reilly, M.D., and Carsrud, A.I. 2000. Competing models of entrepreneurial intentions. Journal of Business Venturing 15(5-6): 411-432.

Laukkanen, M. 2000. Exploring alternative approaches in high-level entrepreneurship education: creating micro-mechanisms for endogenous regional growth. Entrepreneurship and Regional Development 12(1): 25-47.

Leitch, C.and Harrison, R. 1999. Centre for Entrepreneurship, University of Aberdeen, UK. A process model for entrepreneurship education and development. International Journal of Entrepreneurial Behaviour \& Research, 5: 83-109.

Liñán, F. 2008. Skill and value perceptions: how do they affect entrepreneurial intentions? International Entrepreneurship and Management Journal 4(3): 257-72.

Liñán, F., and Chen, Y. 2009. Development and cross-cultural application of a specific instrument to measure entrepreneurial intentions. Entrepreneurship Theory and Practice 33: 593-617.

Low, M., Venkataraman, S. and Srivatsan, V. 1994. Developing an Entrepreneurship Game for Teaching and Research. Simulation \& Gaming 25: 383-401.

Markman, G. D., Balkin, D. B. and Baron, R. A. 2002. Inventors and new venture formation: the effects of general self-efficacy and regretful thinking. Entrepreneurship Theory and Practice 27(2): 149-165.

McLarty, R. 2005. Entrepreneurship among graduates: Towards a measured response. Journal of Management 24: 223-238. 
Nabi, G. and Holden, R. 2008. Graduate entrepreneurship: intentions, education and training. Education + Training 50(7): 545-51.

Nabi, G., Holden, R. and Walmsley, A. 2006. Graduate career-making and business start-up: a literature review. Education + Training 48(5): 373-85.

Nicolau, N., and Shane, S. 2009. Can genetic factors influence the likelihood of engaging in entrepreneurial activity? Journal of Business Venturing 24: 1-22.

Peterman, N.E. and Kennedy, J. 2003. Enterprise Education: Influencing Students' Perceptions of Entrepreneurship. Entrepreneurship Theory and Practice 28: 129-144.

Pittaway, L., and Cope, J. 2007. Entrepreneurship education - a systematic review of the evidence. International Small Business Journal 25: 477-506.

Pittaway, L., Hannon, P., Gibb, A., and Thompson, J. 2009. Assessment practice in enterprise education. International Journal of Entrepreneurial Behaviour and Research 15: 71-93.

Pollitis, D. 2005. The process of entrepreneurial learning: A conceptual framework. Entrepreneurship Theory and Practice 29: 399-424

Rae, D. 2005. Entrepreneurial learning: A narrative based conceptual model. Journal of Small Business and Enterprise Development 12: 323-335.

Rasmussen, E. A., and Sorheim, R. 2006. Action-based entrepreneurship education. Technovation 26: 185-194.

Recommendation 2006/962/CE of European Parliament. D.O. 3914, de 30.12.2006.

Robertson, M. and Collins, A. 2003. The Video Role Model as an Enterprise Teaching Aid. Education \& Training 45: 331-40.

Robinson, P. and Sexton, E. 1994. The effect of education and experience on self-employment success. Journal of Business Venturing 9(2): 141-156.

Robinson, P. B. and Sexton, E. A. 1994. The effect of education and experience on selfemployment success. Journal of Business Venturing 9(2): 141-156.

Ronstadt, R. 1984. Entrepreneurship: Text, Cases and Notes. Lord, Dover.

Saarinen, T. and Ursin, J. 2012. Dominant and emerging approaches in the study of higher education policy change. Studies in Higher Education 37(2), 143-156.

Shane, S. 2004. Encouraging University Entrepreneurship?: The Effect of the Bayh-Dole Act on University Patenting in the United States, Journal of Business Venturing 19: 127-38. 
Shapero, A., and Sokol, L. 1982. The social dimension of entrepreneurship. In C. A. Kent, D. L. Sexton and K. H. Vesper (Eds.), Encyclopedia of entrepreneurship, 72-90. Englewood Cliffs, NJ: Prentice Hall.

Shariff, M.N. and Saud, M. 2009. An Attitude Approach to the Prediction of Entrepreneurship on Students at Institution of Higher Learning in Malaysia. International Journal of Business and Management 4 (4): 129-135.

Shinnar, R., Pruett, M. and Toney, B. 2009. Entrepreneurship education: attitudes across Campus. Journal of Education for Business 84 (3): 151-159.

Smith, A. J., Collins, L. A., and Hannon, P. D. 2006. Embedding new entrepreneurship programmes in UK higher education institutions. Challenges and considerations. Education + Training 48: 555-567.

Souitaris, V. Zerbinati, S., and Al-Laham, A. 2007. Do entrepreneurship programmes raise entrepreneurial intention of science and engineering students? The effect of learning, inspiration and resources. Journal of Business Venturing 22: 566-591.

Stewart, J. and Knowles, V. 2000. Graduate Recruitment and Selection Practices in Small Businesses', Career Development International 5: 2-3.

Storey, D. J. 1994. Understanding the small business sector. Londres: Routledge. Studies in Higher Education 31(2), 169-184.

Thomas, L., Billsberry, J., Ambrosini, V. and Barton, H. 2014. Convergence and Divergence Dynamics in British and French Business Schools: How Will the Pressure for Accreditation Influence these Dynamics? British Journal of Management 25: 305-319.

Thompson, P., Jones-Evans, D., and Kwong, C.C.Y. 2010. Education and entrepreneurial activity: a comparison of White and South Asian Men. International Small Business Journal 28(2): 147-62.

Tkachev, A., and Kolvereid, L. 1999. Self-employment intentions among Russian students. Entrepreneurship \& Regional Development 11: 269-280.

Trow M. 1989. American higher education-Past, present and future. Studies in Higher Education, 14: 5-22,

Ulijn, J., Duill, M. and Robertson, S. 2004. Teaching Business Plan Negotiation: Fostering Entrepreneurship Among Business and Engineering Students. Business Communication Quarterly 67: 41-57. 
Venciana, J.M., Aponte, M., and Urbano, D. 2005. University students' attitudes towards Entrepreneurship: a two-countries comparison. International Entrepreneurship and Management Journal 1(2): 165-182.

Vesper, K. H. 1982. Research on education for entrepreneurship. In C. A. Kent, D. L. Sexton, and K. H. Vesper (Eds.), Encyclopedia of Entrepreneurship, 321-343. Englewood Cliffs, NJ: Prentice-Hall.

Wang, W., Lu, W. and Millington, J.K. 2011. Determinants of entrepreneurial intention among college students in China and USA. Journal of Global Entrepreneurship Research 1(1): 35 44.

White, R. E., Thornhill, S. and Hampson, E. 2006. Entrepreneurs and evolutionary biology: The relationship between testosterone and new venture creation. Organizational Behavior and Human Decision Processes 100: 21-34.

Wilson, F., Kickul, J. and Marlino, D. 2007. Gender, Entrepreneurial Self-Efficacy, and Entrepreneurial Career Intentions: Implications for Entrepreneurship Education. Entrepreneurship Theory and Practice 31(3): 387-406.

$\mathrm{Wu}, \mathrm{S}$., and $\mathrm{Wu}, \mathrm{L}$. 2008. The impact of higher education on entrepreneurial intentions of university students in China. Journal of Small Business and Enterprise Development 15(4): 752-774. 
Table 1. University student profile with entrepreneurial intention (ESIC and ESNE)

\begin{tabular}{|c|c|c|c|c|c|}
\hline \multirow[t]{2}{*}{ Variables } & \multirow[t]{2}{*}{ Items } & \multicolumn{2}{|c|}{ ESIC } & \multicolumn{2}{|c|}{ ESNE } \\
\hline & & $\begin{array}{l}\text { Sampl } \\
\text { e (\%) }\end{array}$ & $\begin{array}{c}\text { Entrepreneu } \\
\text { r }(\%)\end{array}$ & $\begin{array}{c}\text { Sample } \\
(\%)\end{array}$ & $\begin{array}{c}\text { Entrepreneur } \\
(\%)\end{array}$ \\
\hline \multirow[t]{2}{*}{ Sex } & Male & 46.8 & 60.7 & 41.3 & 64.4 \\
\hline & Female & 53.2 & 62.2 & 58.7 & 59.4 \\
\hline \multirow{4}{*}{$\begin{array}{l}\text { Size of } \\
\text { hometown }\end{array}$} & less 1.000 people. & 1.5 & 1,2 & 2.6 & 3.9 \\
\hline & 1.000 to 10.000 people & 12.8 & 13.7 & 10.5 & 9.1 \\
\hline & 10.000 to 100.000 people & 39.4 & 29.6 & 33.6 & 31.1 \\
\hline & more 100.000 people & 47.8 & 55.5 & 58.5 & 56.4 \\
\hline \multirow[t]{9}{*}{ Age } & 18 & 12.1 & 13.7 & 16.3 & 19.9 \\
\hline & 19 & 13.3 & 13.8 & 14.2 & 18.7 \\
\hline & 20 & 16.0 & 15.9 & 13.9 & 15.4 \\
\hline & 21 & 14.1 & 15.2 & 9.6 & 12.0 \\
\hline & 22 & 13.6 & 11.4 & 8.4 & 10.6 \\
\hline & 23 & 9.7 & 8.6 & 10.7 & 6.3 \\
\hline & 24 & 5.8 & 6.1 & 9.9 & 7.2 \\
\hline & 25 & 5.5 & 3.2 & 10.3 & 4.6 \\
\hline & Other & 9.9 & 12.1 & 6.9 & 5.5 \\
\hline \multirow[t]{3}{*}{ Higher School } & Humanities & 28,2 & 29,0 & 22.3 & 18.3 \\
\hline & Social & 36,2 & 38,3 & 30.5 & 26.7 \\
\hline & Technology & 35,6 & 32,7 & 47.2 & 55.0 \\
\hline \multirow[t]{5}{*}{ Year } & $1^{\mathrm{o}}$ & 17,2 & 25,9 & 20.1 & 38.6 \\
\hline & $2^{o}$ & 23,8 & 26,2 & 26.5 & 29.2 \\
\hline & $3^{\circ}$ & 24,6 & 19,7 & 29.3 & 13.5 \\
\hline & $4^{\circ}$ & 21,5 & 14,5 & 24.1 & 18.7 \\
\hline & $5^{\circ}$ & 12,9 & 13,7 & - & - \\
\hline Father & Without studies & 5 & 4,3 & 8.9 & 3.1 \\
\hline & Primary & 32,8 & 23,9 & 20.4 & 9.5 \\
\hline & Higher School & 27,4 & 17,1 & 17.1 & 23.9 \\
\hline & College & 16,1 & 13,7 & 20.7 & 28.8 \\
\hline & University & 18,7 & 41 & 32.9 & 34.7 \\
\hline \multirow[t]{5}{*}{ Mother } & Without studies & 6,4 & 3,2 & 5.2 & 2.1 \\
\hline & Primary & 30,8 & 21,6 & 35.1 & 19.8 \\
\hline & Higher School & 24,6 & 22,3 & 12.0 & 16.2 \\
\hline & College & 13,4 & 14.9 & 19.2 & 23.1 \\
\hline & University & 24,8 & 38,0 & 34.1 & 41.9 \\
\hline \multirow[t]{3}{*}{ Parents Work } & Civil Servant & 21,7 & 17.9 & 26.6 & 19.4 \\
\hline & Organizationally employed & 42,5 & 32,5 & 38.0 & 34.7 \\
\hline & Self-employed & 23,6 & 36.8 & 35.4 & 45.9 \\
\hline \multirow{2}{*}{$\begin{array}{l}\text { Work } \\
\text { Experience }\end{array}$} & Yes & 25.9 & 56,9 & 38.1 & 80.7 \\
\hline & No & 74,1 & 43,1 & 61.9 & 19.3 \\
\hline
\end{tabular}


Table 2. Correlation Matrix (ESIC)

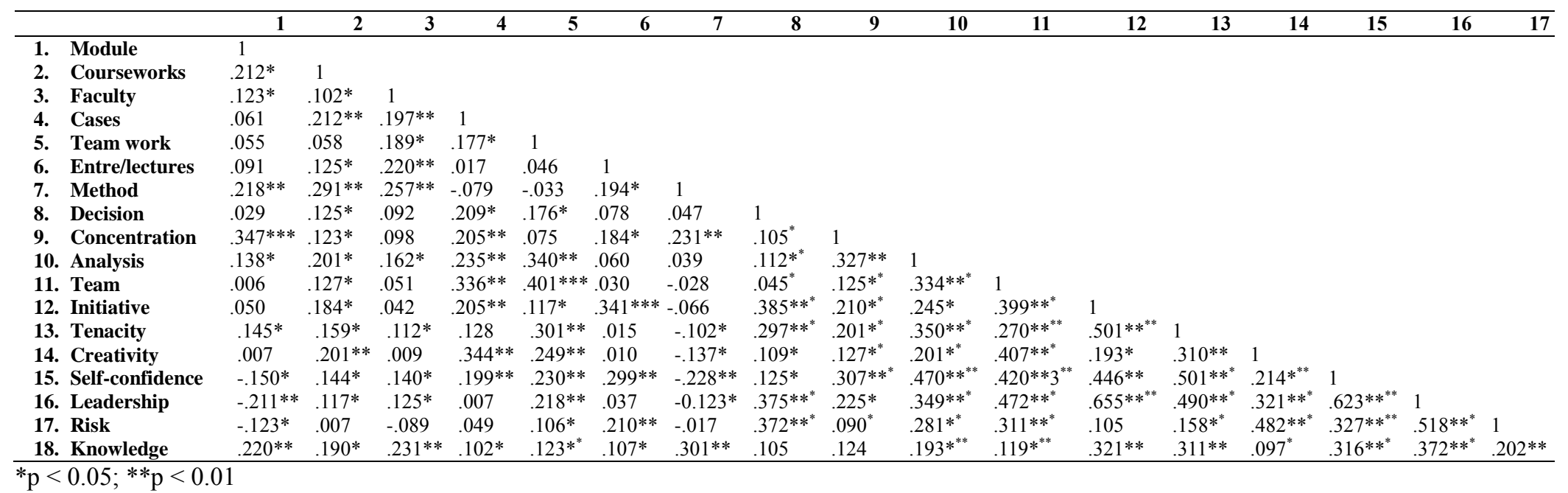

Table 3. Regression Model Competences/Curricular Activities (ESIC)

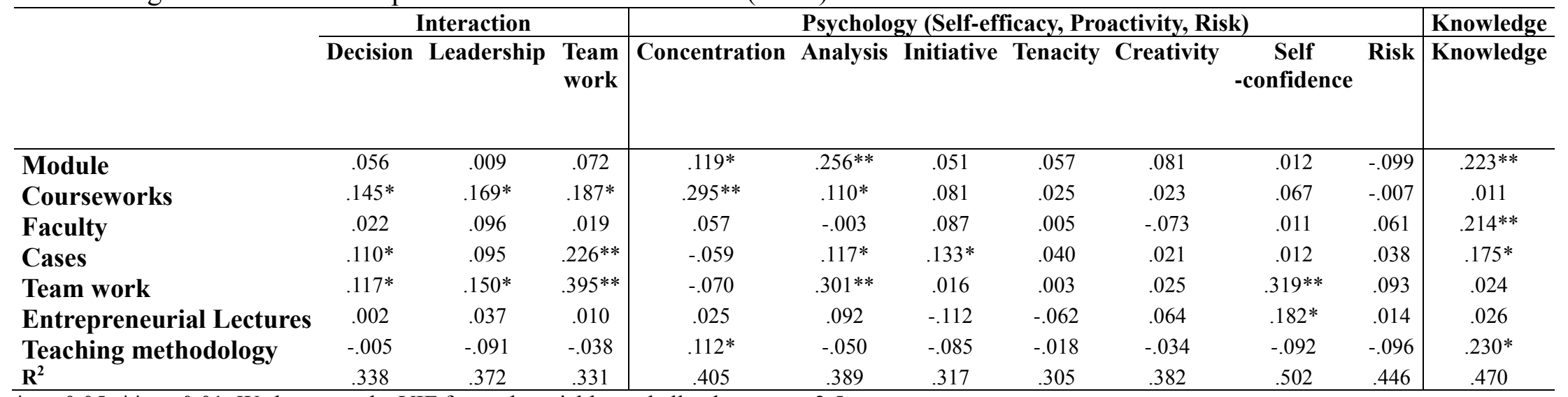

${ }^{*} \mathrm{p}<0.05 ; * * \mathrm{p}<0.01$, We have got the VIF for each variable, and all values are $<2.5$ 
Table 4. Correlation Matrix (ESNE)

\begin{tabular}{|c|c|c|c|c|c|c|c|c|c|c|c|c|c|c|c|c|}
\hline & 1 & 2 & 3 & 4 & 5 & 6 & 7 & 8 & 9 & 10 & 11 & 12 & 13 & 14 & 15 & 16 \\
\hline Module & 1 & & & & & & & & & & & & & & & \\
\hline Courseworks & $.230 * *$ & 1 & & & & & & & & & & & & & & \\
\hline Faculty & $.188^{*}$ & $.157^{*}$ & 1 & & & & & & & & & & & & & \\
\hline Cases & .061 & .003 & .071 & 1 & & & & & & & & & & & & \\
\hline Team work & .012 & .066 & .034 & .048 & 1 & & & & & & & & & & & \\
\hline Entre/lectures & .001 & .025 & .016 & .062 & .040 & 1 & & & & & & & & & & \\
\hline Method & $.218^{* *}$ & $.291 * *$ & $.257 * *$ & -.079 & -.033 & $.194 *$ & 1 & & & & & & & & & \\
\hline Decision & $.209^{*}$ & $.330 * *$ & $.213 *$ & $.225^{*}$ & $.134 *$ & $.115^{*}$ & $.532 * *$ & 1 & & & & & & & & \\
\hline Concentration & $.104 *$ & $.173^{*}$ & $.185^{*}$ & $.158 *$ & $.110 *$ & .080 & $.225^{*}$ & $.435^{* *}$ & 1 & & & & & & & \\
\hline Analysis & $.239^{* *}$ & $.175^{*}$ & $.116^{*}$ & $.198^{*}$ & $.206^{*}$ & .017 & $.318^{* * *}$ & $.321^{* *}$ & $.534 * *$ & 1 & & & & & & \\
\hline Team & $.215^{* *}$ & $.128 *$ & $.110 *$ & $.013 *$ & $.112 *$ & -.095 & $.401 * *$ & $.409^{* *}$ & $.312 * *$ & $.427 * *$ & 1 & & & & & \\
\hline Initiative & $.133^{*}$ & .061 & .099 & .004 & $.188^{*}$ & .048 & $.377 * *$ & $.501^{* *}$ & $.277 * *$ & $.450 * *$ & $.399 * *$ & 1 & & & & \\
\hline Tenacity & $.192 *$ & $.360 * *$ & .031 & $.188^{*}$ & .011 & $.118^{*}$ & $.315^{* *}$ & $.325^{* *}$ & $.411^{* *}$ & $.356^{* *}$ & $.310^{* *}$ & $.310 * *$ & 1 & & & \\
\hline Creativity & .0058 & $.115^{*}$ & $.147 *$ & .005 & .074 & $.125^{*}$ & $.189 *$ & $.314^{* *}$ & $.419 * *$ & $.505 * *$ & $.303 * *$ & $.307 * *$ & $.310^{* *}$ & 1 & & \\
\hline Self-confidence & $.181 *$ & $.118^{*}$ & $.193 *$ & $.256^{* *}$ & $.203 *$ & .012 & $.341 * *$ & $.399 * *$ & $.538 * *$ & $.508^{* *}$ & $.572 * *$ & $.425 * *$ & $.412 * *$ & $.408^{* *}$ & 1 & \\
\hline Leadership & .020 & -.022 & .072 & .017 & .027 & .046 & $.300 * *$ & $.251^{* *}$ & $.401 * *$ & $.419^{* *}$ & $.438 * *$ & $.421 * *$ & $319^{* *}$ & $.570 * *$ & $.431 * *$ & 1 \\
\hline Risk & .079 & $.149^{*}$ & .013 & -.033 & $.299 * *$ & $.110^{*}$ & $.293 * *$ & $.387^{* *}$ & $.277 * *$ & $.458 * *$ & $.322 * *$ & $.299 * *$ & $.340^{* *}$ & $.488 * *$ & $.427 * *$ & $.415^{* *}$ \\
\hline
\end{tabular}

Table 5. Regression Model Competences/Curricular Activities (ESNE)

\begin{tabular}{|c|c|c|c|c|c|c|c|c|c|c|c|}
\hline & \multicolumn{3}{|c|}{ Interaction } & \multicolumn{7}{|c|}{ Psychology (Self-efficacy, Proactivity, Risk) } & \multirow{2}{*}{$\begin{array}{l}\text { Knowledge } \\
\text { Knowledge }\end{array}$} \\
\hline & Decision & Leadership & $\begin{array}{l}\text { Team } \\
\text { work }\end{array}$ & Concentration & Analysis & Initiative & Tenacity & Creativity & $\begin{array}{c}\text { Self } \\
- \\
\text { confidence }\end{array}$ & Risk & \\
\hline Module & .023 & .077 & .015 & $.268 * *$ & $.324 * *$ & $.350 * *$ & .099 & $.309 * *$ & $.239 *$ & $.123 *$ & .009 \\
\hline Courseworks & .037 & .028 & -.093 & $.228^{*}$ & $.188^{*}$ & $.225^{*}$ & $.135^{*}$ & $.209 * *$ & $.130^{*}$ & $.127 *$ & -.017 \\
\hline Faculty & $.193^{*}$ & $.107 *$ & -.045 & -.009 & $.128^{*}$ & -.079 & .008 & $.114^{*}$ & $.280 * *$ & $.117 *$ & .038 \\
\hline Cases & .005 & -.060 & -.014 & .016 & .025 & .037 & -.015 & .011 & .074 & .043 & -.002 \\
\hline Team work & .082 & .010 & $.339 * *$ & .017 & .003 & .025 & .001 & .094 & .022 & .009 & .004 \\
\hline $\begin{array}{l}\text { Entrepreneurial } \\
\text { Lectures }\end{array}$ & .031 & .092 & .061 & .082 & $.110^{*}$ & $.127 *$ & .030 & .112 & $.250 * *$ & $.145^{*}$ & .070 \\
\hline $\begin{array}{l}\text { Teaching } \\
\text { methodology }\end{array}$ & -.090 & .006 & -.205 & .094 & $.107 *$ & $.193 *$ & $.122 *$ & $.220 * *$ & $.139 *$ & .037 & .009 \\
\hline $\mathbf{R}^{2}$ & .401 & .315 & .490 & .311 & .350 & .321 & .367 & .380 & .425 & .314 & .310 \\
\hline
\end{tabular}

${ }^{*} \mathrm{p}<0.05 ; * * \mathrm{p}<0.01$. We have got the VIF for each variable, and all values are $<2.5$ 
Table 6. Correlation Matrix

\begin{tabular}{|c|c|c|c|c|c|c|c|c|c|c|c|c|c|}
\hline Variables & 1 & 2 & 3 & 4 & 5 & 6 & 7 & 8 & 9 & 10 & 11 & 12 & 13 \\
\hline 1. Attitude & 1.000 & & & & & & & & & & & & \\
\hline 2. Control & $0.125 *$ & 1.000 & & & & & & & & & & & \\
\hline 3. Curricula & $0.107^{*}$ & $0.133^{*}$ & 1.000 & & & & & & & & & & \\
\hline 4. Extra-curricula & 0.025 & $0.102 *$ & $0.118^{*}$ & 1.000 & & & & & & & & & \\
\hline 5. Sex & 0.034 & 0.091 & 0.055 & 0.003 & 1.000 & & & & & & & & \\
\hline 6. Size & 0.082 & 0.018 & 0.009 & 0.079 & -0.099 & 1.000 & & & & & & & \\
\hline 7. Age & -0.045 & -0.056 & 0.048 & -0.051 & -0.057 & -0.099 & 1.000 & & & & & & \\
\hline 8. Higher School & 0.037 & 0.088 & 0.093 & 0.082 & 0.102 & -0.042 & 0.150 & 1.000 & & & & & \\
\hline 9. Year & 0.070 & 0.021 & 0.042 & 0.067 & 0.030 & 0.061 & 0.008 & 0.069 & 1.000 & & & & \\
\hline 10. Parents Education & 0.078 & 0.099 & 0.045 & 0.004 & 0.072 & 0.059 & 0.034 & 0.053 & 0.053 & 1.000 & & & \\
\hline 11. Parents Work & $0.107 *$ & 0.085 & 0.052 & 0.096 & 0.081 & 0.037 & 0.099 & $0.126^{*}$ & 0.041 & 0.042 & 1.000 & & \\
\hline 12. Experiences & $0.163^{*}$ & $0.152 *$ & 0.006 & 0.038 & 0.062 & -0.011 & 0.096 & 0.057 & 0.089 & 0.010 & -0.023 & 1.000 & \\
\hline 13. Intentions & $0.191 * *$ & $0.117 *$ & 0.097 & 0.081 & 0.045 & 0.024 & 0.028 & 0.008 & -0.097 & $0.103 *$ & 0.233 & $0.240 * *$ & 1.000 \\
\hline
\end{tabular}

Table 7. Correlation Matrix (ESNE)

\begin{tabular}{|c|c|c|c|c|c|c|c|c|c|c|c|}
\hline Variables & 1 & 2 & 3 & 4 & 5 & 6 & 7 & 8 & 9 & 10 & 11 \\
\hline 1. Attitude & 1.000 & & & & & & & & & & \\
\hline 2. Control & 0.203 & 1.000 & & & & & & & & & \\
\hline 3. Sex & 0.091 & 0.070 & 1.000 & & & & & & & & \\
\hline 4. Size & 0.087 & 0.025 & 0.008 & 1.000 & & & & & & & \\
\hline 5. Age & 0.031 & -0.044 & 0.094 & -0.015 & 1.000 & & & & & & \\
\hline 6. Higher School & 0.075 & 0.031 & 0.086 & 0.018 & 0.004 & 1.000 & & & & & \\
\hline 7. Year & 0.003 & 0.028 & 0.072 & 0.030 & 0.035 & 0.024 & 1.000 & & & & \\
\hline 8. Parents Education & 0.089 & 0.065 & 0.012 & 0.054 & 0.090 & 0.028 & 0.025 & 1.000 & & & \\
\hline 9. Parents Work & $0.184^{*}$ & $0.130 *$ & 0.018 & 0.060 & 0.087 & 0.072 & 0.034 & 0.078 & 1.000 & & \\
\hline 10. Experiences & $0.291 * *$ & $0.187^{*}$ & 0.038 & 0.024 & 0.061 & 0.013 & 0.071 & 0.052 & $0.110^{*}$ & 1.000 & \\
\hline 11. Intentions & $0.245 * *$ & $0.101^{*}$ & 0.019 & 0.005 & 0.049 & 0.052 & 0.005 & $0.126^{*}$ & $0.104 *$ & $0.205 * *$ & 1.000 \\
\hline
\end{tabular}

$* \mathrm{p}<0.05 ; * * \mathrm{p}<0.01$ 
Table 8. Causal Model (Attitude and Behavioural Control as DV; ESIC and ESNE)

\begin{tabular}{|c|c|c|c|c|c|c|c|c|}
\hline & \multicolumn{4}{|c|}{ ESIC } & \multicolumn{4}{|c|}{ ESNE } \\
\hline & \multicolumn{2}{|c|}{ Attitude } & \multicolumn{2}{|c|}{ Behavioural Control } & \multicolumn{2}{|c|}{ Attitude } & \multicolumn{2}{|c|}{ Behavioural Control } \\
\hline & M1 & M2 & M3 & M4 & M1 & M2 & M3 & M4 \\
\hline Curriculum & & $0.351 * * *$ & & $0.394 * * *$ & & $0.150^{*}$ & & 0.017 \\
\hline Extra-Curriculum & & $0.311 * *$ & & $0.160 *$ & & 0.018 & & 0.003 \\
\hline Sex & 0.072 & 0.018 & 0.019 & 0.045 & 0.007 & 0.025 & 0.007 & 0.029 \\
\hline Size & 0.016 & 0.067 & 0.053 & 0.053 & 0.094 & 0.046 & 0.094 & 0.038 \\
\hline Age & 0.045 & 0.042 & 0.010 & 0.010 & 0.013 & 0.027 & 0.013 & 0.087 \\
\hline Higher School & 0.091 & 0.040 & 0.035 & 0.068 & 0.038 & 0.085 & 0.038 & 0.050 \\
\hline Year & 0.085 & -0.088 & -0.082 & 0.036 & 0.024 & 0.061 & 0.024 & 0.022 \\
\hline Parents Education & $0.152 *$ & $0.152 *$ & $0.178 *$ & $0.132 *$ & 0.093 & 0.060 & 0.093 & 0.098 \\
\hline Parents Work & $0.188^{*}$ & $0.199 *$ & $0.121 *$ & $0.271 *$ & $0.125 *$ & $0.143 *$ & $0.125^{*}$ & $0.141^{*}$ \\
\hline Experiences & $0.122 *$ & $0.137 *$ & $0.201 *$ & $0.105 *$ & $0.239 *$ & $0.297 *$ & $0.214^{*}$ & $0.204^{*}$ \\
\hline $\mathbf{R}^{2}$ & 0.37 & 0.45 & 0.25 & 0.40 & 0.29 & 0.34 & 0.32 & 0.31 \\
\hline
\end{tabular}

${ }^{*} \mathrm{p}<0.1 ; *{ }^{*} \mathrm{p}<0.01$. We have got the VIF for each variable, and all values are $<2.5$

Table 9. Causal Model (Intention as DV; ESIC)

\begin{tabular}{|c|c|c|c|c|c|c|}
\hline & M1 & M2 & M3 & M4 & M5 & M6 \\
\hline Attitude & & $0.402 * * *$ & & & & $0.352 * *$ \\
\hline Control & & $0.265^{*}$ & & & & $0.182^{*}$ \\
\hline Curricula & & & 0.089 & & & 0.024 \\
\hline $\begin{array}{l}\text { Extra- } \\
\text { curricula }\end{array}$ & & & 0.071 & & & 0.050 \\
\hline $\begin{array}{l}\text { Attitud } x \\
\text { Curricula }\end{array}$ & & & & $0.259^{*}$ & & $0.170^{*}$ \\
\hline $\begin{array}{l}\text { Attitud } x \\
\text { ExtraC. }\end{array}$ & & & & $0.183^{*}$ & & $0.158^{*}$ \\
\hline $\begin{array}{l}\text { Control } \mathbf{x} \\
\text { Curriculum }\end{array}$ & & & & & $0.220 *$ & $0.190^{*}$ \\
\hline $\begin{array}{ll}\text { Control } & x \\
\text { ExtraC. } & \end{array}$ & & & & & $0.131 *$ & $0.115^{*}$ \\
\hline Sex & 0.017 & 0.021 & 0.053 & 0.080 & 0.078 & 0.030 \\
\hline Size & 0.052 & 0.094 & 0.087 & 0.032 & 0.035 & 0.054 \\
\hline Age & 0.050 & 0.014 & 0.010 & 0.055 & 0.034 & 0.052 \\
\hline $\begin{array}{l}\text { Higher } \\
\text { School }\end{array}$ & 0.019 & 0.083 & 0.036 & 0.018 & 0.030 & 0.078 \\
\hline Year & 0.067 & 0.065 & 0.062 & 0.024 & 0.067 & 0.060 \\
\hline $\begin{array}{l}\text { Parents } \\
\text { Education }\end{array}$ & $0.102 *$ & $0.198^{*}$ & $0.190 *$ & $0.133^{*}$ & $0.149 *$ & $0.144^{*}$ \\
\hline $\begin{array}{l}\text { Parents } \\
\text { Work }\end{array}$ & $0.113^{*}$ & $0.182 *$ & $0.123 *$ & $0.136^{*}$ & $0.132 *$ & $0.127 *$ \\
\hline Experiences & $0.162 *$ & $0.139 *$ & $0.145^{*}$ & $0.158^{*}$ & $0.201 *$ & $0.126^{*}$ \\
\hline $\mathbf{R}^{2}$ & 0.30 & 0.35 & 0.33 & 0.35 & 0.26 & 0.43 \\
\hline
\end{tabular}


Table 10. Causal Model (Intention as DV; ESNE)

\begin{tabular}{lllll}
\hline & M1 & M2 & M3 & M4 \\
\cline { 2 - 5 } Attitude & & $0.253^{* *}$ & & $0.211^{*}$ \\
Control & & $0.118^{*}$ & & $0.195^{*}$ \\
Sex & 0.009 & 0.050 & 0.092 & 0.010 \\
Size & 0.047 & 0.097 & 0.051 & 0.033 \\
Age & 0.092 & 0.081 & 0.078 & 0.039 \\
Higher School & 0.074 & 0.065 & 0.044 & 0.047 \\
Year & 0.056 & 0.015 & 0.045 & 0.079 \\
Parents Education & 0.093 & 0.089 & 0.003 & 0.020 \\
Parents Work & $0.124^{*}$ & $0.161^{*}$ & $0.119^{*}$ & 0.165 \\
Experiences & $0.231^{* *}$ & $0.239^{* *}$ & $0.195^{*}$ & $0.191^{* *}$ \\
$\mathbf{R}^{\mathbf{2}}$ & 0.22 & 0.34 & 0.34 & 0.37 \\
\hline
\end{tabular}

${ }^{*} \mathrm{p}<0.1 ;{ }^{* *} \mathrm{p}<0.01$. We have got the VIF for each variable, and all values are $<2.5$ 